\title{
КОРРЕКЦИЯ АDМА-ПОДОБНОЙ ПРЕЭКЛАМПСИИ АЦЕТИЛСАЛИЦИЛОВОЙ КИСЛОТОЙ В НИЗКОЙ ДОЗЕ
}

\author{
А.С. Нетребенко, О.В. Северинова, М.В. Покровский, \\ М.С. Стефанова
}

ФГАОУ ВО «Белгородский государственный национальный исследовательский университет», ул. Победы, д.85, г. Белгород, 308015, Российская Федерация.

DOI: 10.19163/MedChemRussia2021-2021-468

E-mail: netreba@bsu.edu.ru

При оценке уровня концентрации конечных метаболитов оксида азота в плазме у крыс с ADMA - подобной преэклампсией, которым вводились низкие дозы ацетилсалициловой кислоты (АСК) в комбинации с метилдопой, было выявлено статистически значимое $(p<0,05)$ по отношению к группамс использованием исследуемых фармакологических агентов в качестве монотерапии. Комбинированное введение исследуемых фармакологических агентов снижало протеинурию практически до уровня животных с физиологически протекающей беременностью (табл. 1).

Исследование содержания жидкости в тканях большого сальника у животных с экспериментальной преэклампсией выявлено статистически значимое $(p<0,05)$ снижение данного показателя при сочетанном введении низкой дозы ацетилсалициловой кислоты и метилдопы в сравнении с группой «нелеченных» животных и достижением его уровня интактных животных (табл. 1).

Табл. 1

Коррекция протеинурии, отеков и NO синтезирующей функции ацетилсалициловой кислоты в комбинации с метилдопой при АDМА-подобной преэклампсии

\begin{tabular}{|l|l|l|l|}
\hline \multicolumn{1}{|c|}{ Показатель } & \multicolumn{1}{|c|}{$\begin{array}{c}\text { No } \\
\text { (ммоль/л) }\end{array}$} & \multicolumn{1}{|c|}{$\begin{array}{c}\text { Протеинурия } \\
\text { (г/л) }\end{array}$} & $\begin{array}{c}\text { Отек большого } \\
\text { сальника (\%) }\end{array}$ \\
\hline Интактные животные & $2,28 \pm 0,05^{y}$ & $0,23 \pm 0,051^{y}$ & $44,39 \pm 1,62^{y}$ \\
\hline L-NAME & $1,3 \pm 0,02^{*}$ & $2,2 \pm 0,177^{*}$ & $55,02 \pm 1,74^{*}$ \\
\hline L-NAME+Метлдопа 0,086 г/кг & $1,54 \pm 0,04^{* y}$ & $1,22 \pm 0,103^{* y}$ & $49,43 \pm 1,64^{* y}$ \\
\hline L-NAME+ACK 10мг/кг/сут & $1,75 \pm 0,03^{* y}$ & $0,86 \pm 0,147^{* y}$ & $49,33 \pm 1,94^{y}$ \\
\hline $\begin{array}{l}\text { L-NAME+ ACK 10мг/кг/сут + Метилдопа } \\
\text { 0,086 г/кг }\end{array}$ & $2,12 \pm 0,03^{y}$ & $0,33 \pm 0,09^{y}$ & $44,32 \pm 2,1^{y}$ \\
\hline
\end{tabular}

Примечание: NO - уровень оксида азота (ммоль/л); ${ }^{*}-\mathrm{p}<0,05$ в сравнении с группой интактных животных; ${ }^{y}-$ p<0,05 в сравнении с группой L-NAME; *y - p<0,05 в сравнении с группой интактных животных и группой L-NAME. 